\title{
The Pituitary Gland is a Novel Major Site of Action of Metformin in Non-Human Primates: a Potential Path to Expand and Integrate Its Metabolic Actions
}

\author{
Mari C. Vázquez-Borrego ${ }^{a, b, c, d} \quad$ Antonio C. Fuentes-Fayos ${ }^{a, b, c, d} \quad$ Manuel D. Gahete $e^{a, b, c, d}$ \\ Justo P. Castaño $o^{a, b, c, d} \quad$ Rhonda D. Kineman ${ }^{e}$ Raúl M. Luque $e^{a, b, c, d}$ \\ a Maimonides Institute of Biomedical Research of Cordoba (IMIBIC), Cordoba, bepartment of Cell \\ Biology, Physiology and Immunology, University of Cordoba, Cordoba, 'Reina Sofia University Hospital \\ (HURS), Cordoba, 'CIBER Physiopathology of Obesity and Nutrition (CIBERobn), Cordoba, Spain, \\ eResearch and Development Division, Jesse Brown Veterans Affairs Medical Center and, Department \\ of Medicine, Section of Endocrinology, Diabetes, and Metabolism, University of Illinois at Chicago, \\ Chicago, USA
}

\section{Key Words}

Pituitary $\bullet$ Metformin $•$ Phenformin $•$ Growth hormone $・$ Primates $•$ Hormones

\begin{abstract}
Background/Aims: Biguanides are anti-hyperglycaemic agents used to treat diabetes by acting primarily on the liver, inhibiting hepatic gluconeogenesis. However, biguanides may target other key metabolic tissues to exert beneficial actions. As the "master endocrine gland", the pituitary is a true homeostatic sensor that controls whole body homeostasis and metabolism by integrating central and peripheral signals. However, whether the pituitary is a primary site of biguanides action in normal adult humans/primates remains unknown. Therefore, we aimed to elucidate the direct effects of two biguanides (metformin/phenformin) on the expression and secretion of all anterior pituitary hormones in two non-human primate species (Papio anubis and Macaca fascicularis), and the molecular/signalling-mechanisms behind these actions. Methods: Primary pituitary cell cultures from baboons and macaques were used to determine the direct impact of metformin/phenformin (alone and combined with primary regulators) on the functioning of all pituitary cell-types (i.e. expression/secretion/signaling-pathways, etc). Results: Metformin/phenformin inhibited basal, but not GHRH/ghrelin-stimulated GH/ACTH/ $\mathrm{FSH}$-secretion and GH/POMC-expression, without altering secretion or expression of other pituitary hormones (PRL/LH/TSH), FSH-expression or cell viability in both primate models. These biguanide actions are likely mediated through modulation of: 1 ) common (mTOR/ PI3K/intracellular- $\mathrm{Ca}^{2+}$ mobilization) and distinct (MAPK) signaling pathways; and 2) gene expression of key receptors regulating somatotrope/corticotrope/gonadotrope function (i.e. upregulation of SSTR2/SSTR5/INSR/IGF1R/LEPR). Conclusion: The pituitary gland is a primary
\end{abstract}




\section{Cellular Physiology Cell Physiol Biochem 2018;49:1444-1459 \\ \begin{tabular}{l|l|l} 
DOI: 10.1159/000493448 & $\begin{array}{l}\text { O 2018 The Author(s). Published by S. Karger AG, Basel } \\
\text { www.karger.com/cpb }\end{array}$
\end{tabular} \\ Vázquez-Borrego et al.: Actions of Metformin on Primate Pituitary Function}

target of biguanide actions wherein they modulate somatotrope/corticotrope/gonadotropefunction through multiple molecular/signaling pathways in non-human primate-models. This suggests that the well-known metabolic effects of biguanides might be, at least in part, influenced by their actions at the pituitary level.

\section{Introduction}

(C) 2018 The Author(s)

Published by S. Karger AG, Basel

Biguanides are a synthetic class of antidiabetic (anti-hyperglycaemic) agents constituted by two $\mathrm{N}$-linked guanidine rings (i.e. metformin and phenformin), whose origin derives from galegine (isoamylene guanidine), a natural compound found in Galega officinalis [1]. Metformin has been the most frequently prescribed drug used to treat type-2 diabetes (T2D) for many years, and has been found to be safe and efficacious both as monotherapy and in combination with other oral antidiabetic agents. However, the sites and mechanisms of actions of metformin have been only partially explored and remain somewhat controversial. Specifically, the liver is presumed to be the primary site of metformin function, as the antihyperglycemic effect of metformin is mainly due to the inhibition of hepatic gluconeogenesis, wherein AMP-activated protein kinase (AMPK), a protein kinase that plays a key role in maintaining energy homeostasis, is assumed to be the prime hepatic target of metformin [2,3]. However, recent studies have revealed that metformin, besides its glucoselowering action, might exert additional, promising actions for the modulation of whole body homeostasis and metabolism, by specifically targeting other key endocrine/metabolic tissues, as well as by exerting other positive effects through additional mechanisms of actions (i.e. beneficial use in the treatment of cancer, cardiovascular diseases, aging, immunity and polycystic ovarian syndrome, etc.); although, these and other effects and mechanism of actions of metformin require further investigation [4-12]. Actually, it is still unclear if AMPK is the central mediator of metformin effects in all metabolic tissues and, therefore, the existence of both AMPK-dependent and independent mechanisms has been proposed $[2,13,14]$.

In this context, the pituitary gland, classically known as the "master endocrine gland", is currently considered also a true metabolic sensor for whole body function, and one of the most important players in the control of body homeostasis, integrating central and peripheral signals [15]. Specifically, the five hormone-producing cells of the adenohypophysis (i.e. GHproducing somatotropes, PRL-producing lactotropes, ACTH-producing corticotropes, TSHproducing thyrotropes, and FSH/LH-producing gonadotropes) receive multiple central and peripheral signals and, the integration of these signals results in the modulation of the corresponding hormonal secretions, which, in turn, control key peripheral organs and tissues related with essential metabolic functions such as growth, lactation, stress responses, appetite, reproduction, whole-body metabolism and puberty [16]. Inasmuch as metformin is involved in the modulation of a wide variety of metabolic processes in humans, it seems reasonable to think that this agent could exert some of these effects by directly influencing pituitary gland function. Indeed, some observations suggest that metformin is able to modify pituitary hormone levels in some pathological conditions (i.e. patients with pituitary adenomas, hypothyroidism or polycystic ovary syndrome (PCOS) $[17,18])$, although these results are scattered, inconsistent and controversial.

To the best of our knowledge, no studies have explored hitherto, on suitable models, how metformin or other biguanides agents can modulate directly the function of all the anterior pituitary cell types in normal adult humans or in primate species, and what intracellular signaling pathways would be involved in these putative actions. Accordingly, in the present study, we aimed at determining, for the first time, the direct effects of metformin and phenformin on the expression and secretion of all anterior pituitary hormones in two primate model species that closely resemble human physiology: Papio anubis (baboons) and Macaca fascicularis [19-21]. In addition, we also used primary pituitary cell cultures from baboons to better understand the mechanisms behind these actions, by evaluating the effects of these biguanides on the expression of selected key receptors and transcriptional factors involved in the normal functioning of the pituitary cell types, and by assessing the precise contribution of different signaling pathways in the actions of metformin using standard pharmacological (inhibitory) approaches. 


\section{Cellular Physiology Cell Physiol Biochem 2018;49:1444-1459

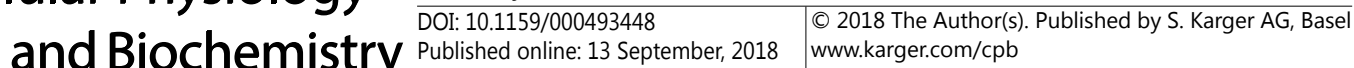 \\ Vázquez-Borrego et al.: Actions of Metformin on Primate Pituitary Function}

\section{Materials and Methods}

\section{Reagents}

All reagents and inhibitors of intracellular signaling pathways used in this study were purchased from Sigma-Aldrich (St. Louis, MO) unless otherwise specified. Ghrelin was purchased from Phoenix Pharmaceuticals (Burlingame, CA). $\alpha$-MEM, HEPES, horse serum, and penicillin-streptomycin were obtained from Invitrogen (Grand Island, NY), and U73122 was purchased from Cayman Chemical (Ann Arbor, MI).

\section{Animals and tissue collection}

Pituitary glands were obtained from randomly cyclic female baboons (Olive Baboon; Papio anubis; $\mathrm{n}=6 ; 7-12$ years of age) and macaques (Macaca fascicularis; $\mathrm{n}=3 ; 7$ years of age) within 15 min after sodium pentobarbital overdose as previously reported $[22,23]$. The animals represent control animals from a breeding colony at the University of Illinois at Chicago (UIC). All procedures were approved and conducted under the Institutional Animal Care and Use Committee at the UIC (Chicago, IL), and all methods were carried out in accordance with relevant guidelines and regulations. Right after the animals were euthanized, pituitaries were excised, placed in sterile cold $\left(4^{\circ} \mathrm{C}\right.$ ) basic media ( $\alpha$-MEM with: $0.15 \%$ BSA, 6 nM HEPES, $10-\mathrm{IU} / \mathrm{mL}$ penicillin, and $10-\mu \mathrm{g} / \mathrm{mL}$ streptomycin) and immediately transported to the laboratory in sterile conditions.

\section{Primary pituitary cell cultures}

Pars distalis of the pituitary was isolated, washed twice in fresh media, and cut into small pieces $(\sim 20-$ $40 \mathrm{mg}$ ) with surgical blades; then, fragments were incubated in $30 \mathrm{~mL}$ S-MEM medium complemented with $0.3 \%$ trypsin (Beckton, Dickinson and Company, Sparks, MD, USA) in a spinner flask (Bellco Glass, Vineland, $\mathrm{NJ}$, USA) for $2 \mathrm{~h}$ at $37^{\circ} \mathrm{C}$ under gentle shaking to obtain dispersed single cells for culture, as previously reported [22-25]. To avoid fibroblast contamination, suspensions of dispersed pituitary cells were filtered through a nylon gauze of $130 \mu \mathrm{M}$-mesh and cultured in media with D-Valine (replaced for L-valine) to selectively inhibit fibroblast proliferation/overgrowth. In addition, visual inspection of primary cell cultures at the time of experimental assays showed no sign of cells displaying the typical fibroblast-like morphology.

Single cells (50.000-200.000 cells/ well) were plated onto 48- or 24-well plates in media containing $10 \%$ fetal horse serum. After $36 \mathrm{~h}$ incubation $\left(37^{\circ} \mathrm{C}, 5 \% \mathrm{CO}_{2}\right)$, media was removed and cells pre-incubated for $1 \mathrm{~h}$ with fresh, warm $\left(37^{\circ} \mathrm{C}\right)$ serum-free medium to stabilize basal hormone secretion. After this preincubation period, cells were incubated with serum-free medium alone (controls) or serum-free media containing the following treatments: 1$)$ metformin or phenformin alone $\left(10^{-7}\right.$ to $5 \times 10^{-3} \mathrm{M}$; dose-response experiment; $4 \mathrm{~h}$ incubation; doses selected based on previous studies [12, 26, 27]); 2) metformin or phenformin alone $\left(5 \times 10^{-3} \mathrm{M}\right)$ for $4 \mathrm{~h}$ and $24 \mathrm{~h}$ (time-course experiment); 3) metformin or phenformin alone $\left(5 \times 10^{-3} \mathrm{M}\right)$ or in combination with GH-releasing hormone (GHRH; $\left.10 \mathrm{nM}\right)$, acylated-ghrelin (10 nM) or gonadotropin-releasing hormone $(\mathrm{GnRH}, 10 \mathrm{nM}$ ) for $4 \mathrm{~h}$. Cells from different pituitaries (i.e. $\mathrm{n}=6$ from baboons and $n=3$ from macaques) were not pooled. It should be noted that, given the limited source of macaque cell preparations $(n=3)$, and the amount of cells obtained after dispersion of the pituitary glands, we were not able to reproduce the total amount of experiments included herein in both primate species.

To study the intracellular signaling pathways involved in the metformin-mediated actions on baboon pituitary hormone release, after the $1 \mathrm{~h}$ pre-incubation period with serum-free media, cells were incubated for an additional 90-minute period in serum-free media containing the following inhibitors of selected intracellular signaling pathways: mammalian target of rapamycin (mTOR; rapamycin; $10 \mu \mathrm{M}$ ), phosphatidylinositol 3-kinase activity (PI3K; wortmannin; $1 \mu \mathrm{M}$ ), mitogen-activated protein kinase activity

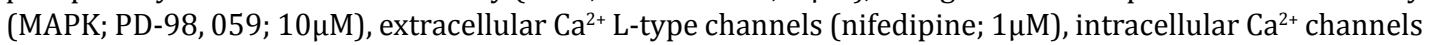
(thapsigargin; $10 \mu \mathrm{M}$ ), adenylyl cyclase (AC; MDL-12, 330A; 10 $\mu \mathrm{M}$ ), and phospholipase-C (PLC; U73122; $50 \mu \mathrm{M}$ ). Thereafter, the media were replaced with media with the specific inhibitor alone (vehicle) or media with the inhibitor containing metformin $\left(5 \times 10^{-3} \mathrm{M}\right)$, and cells were incubated for an additional $4 \mathrm{~h}$. Additional controls consisted of serum-free media alone or media with metformin (in all cases without inhibitors). Doses for GHRH, acylated-ghrelin, GnRH or inhibitors of intracellular signaling pathways were selected based on previous studies [22-25, 28,29]. At the end of the corresponding incubation periods with the different treatments, media were collected for hormone analysis using commercial ELISAs (see section below) and, in selected cases, cells were processed for total RNA recovery and assessment of mRNA levels by quantitative real-time PCR (qPCR; see section below).

Hormone release analysis.

GH, PRL, ACTH, LH, FSH and TSH hormone concentrations in the culture media were measured using human commercial ELISAs [Human: GH, PRL, ACTH, FSH, LH and TSH (reference numbers: EIA-1787, EIA- 


\section{Cellular Physiology Cell Physiol Biochem 2018;49:1444-1459 and Biochemistry Published online: 13 September, 2018 \begin{tabular}{l|l} 
DOI: 10.1159/000493448 & $\begin{array}{l}\text { C } 2018 \text { The Author(s). Published by S. Karger AG, Basel } \\
\text { www.karger.com/cpb }\end{array}$
\end{tabular} \\ Vázquez-Borrego et al.: Actions of Metformin on Primate Pituitary Function}

1291, EIA-3647, EIA-1288, EIA-1289 and EIA-1790, respectively; DRG, Mountainside, NJ)], as previously described [22, 24]. All the assays were performed following the manufacturer's instructions where the information regarding specificity, detectability and reproducibility for each of the assays can be accessed at the websites of the indicated company.

\section{RNA isolation, reverse transcription and qPCR of primate transcripts}

Primary pituitary cell cultures from baboons were processed for recovery of total RNA and the subsequent quantification of the amount of RNA recovered using kits and methods previously described $[23,29]$. Briefly, total RNA was extracted using the Absolutely RNA RT-PCR Miniprep Kit (Stratagene, La Jolla, CA) with deoxyribonuclease treatment. The amount of RNA recovered was quantified by the Ribogreen RNA quantification kit (Molecular Probes, Eugene, OR) and reverse transcribed in a $20 \mu$ l volume using randomhexamer primers and the cDNA First Strand Synthesis kit (MRI Fermentas, Hanover, MD). cDNAs were treated with ribonuclease H (1 U; MRI Fermentas) and amplified by qPCR using a Stratagene Mx3000p real-time PCR machine and the Brilliant III Ultra-Fast SYBR® QPCR Master Mix (Stratagene, La Jolla, CA, USA). To estimate mRNA copy number, samples were run against specific synthetic standards $\left(1-10^{6}\right.$ copies of synthetic cDNA template for each transcript of interest) run on the same plate. Details regarding the development, validation, and application of a qPCR as well as the specific sets of primers sequences to measure expression levels of primates transcripts included in this study, including cyclophilin A (PPIA; used as a reference, housekeeping gene), have been reported previously [22-24, 29, 30]. New baboon primer sequences were used in the present study to amplify GNRHR, (sense, TGCCTCTTCATCATCCCTCTT and antisense AGTCTTCAGCCGTGCTCTTG; accession number, NM000406; product size, $144 \mathrm{pb}$ ) and LEPR (sense, GGAAGGAGTGGGAAAACCAAAG and antisense, CCAAGCAATAAGATGGAAGAGG; accession number, XM_009210050.2; product size, 126 pb). To control for variations in the amount of RNA used in the RT reaction and the efficiency of the RT reaction, mRNA copy numbers of the baboon transcripts analyzed were adjusted by cyclophilin-A expression, where baboon cyclophilin-A mRNA levels did not significantly vary between experimental groups (data not shown).

\section{Cell viability}

In order to determine if metformin or phenformin altered cell viability, trypan blue (Sigma, St. Louis, MO) assay was used as previously reported [22], following the manufacturer's instructions. Specifically, macaque and baboon primary pituitary cell cultures were plated onto 48-well tissue culture plates (100, 000 cells/well: 3 wells/treatment) in basic medium containing $10 \%$ horse serum. After $24 \mathrm{~h}$ of incubation $\left(37^{\circ} \mathrm{C}, 5 \% \mathrm{CO}_{2}\right)$, medium was removed, and cells were preincubated for $4 \mathrm{~h}$ in fresh, warm $\left(37^{\circ} \mathrm{C}\right)$ serum-free medium to induce cells synchronization. Then, cells were washed 3 times with serum-free medium and incubated $24 \mathrm{~h}$ with serum-free medium alone (controls) or containing metformin or phenformin $\left(5 \times 10^{-3}\right.$ M). After that, cell viability was evaluated using trypan blue reagent (counting a minimum of 300 cells/ well/treatment).

\section{Statistical analysis}

Samples from all groups within an experiment were processed at the same time. Results are expressed as mean \pm SEM and were obtained from at least three separate, independent experiments carried out on different days, and with different cell preparations (3-4 replicate culture wells/treatment/experiment). To normalize values within each treatment and minimize intragroup variations in the different experiments (i.e. different age of the donor, metabolic environment, stage of the estrus cycle, etc.), the values obtained were compared with the corresponding vehicle-treated controls (set at 100\%), where this style of data presentation does not alter the relative differences between the different biguanides-treated and vehicletreated groups. Differences between experimental groups were assessed by one-way ANOVA [or two-way ANOVA when the intracellular signaling pathways, with treatments with and without (controls) specific inhibitors, were studied] followed by Fisher's test for multiple comparisons. $P<0.05$ was considered significant difference. All statistical analyses were performed using GB-STAT software package (Dynamic Microsystems, Inc., Silver Spring, MD).

\section{Results}

Direct effects of metformin and phenformin on primate pituitary hormone release.

Incubation of cultured baboon and macaque pituitary cells with increasing doses of metformin (from $10^{-7}$ to $5 \times 10^{-3} \mathrm{M}$ ) for $4 \mathrm{~h}$ revealed significant inhibitory effects on GH, ACTH and FSH release in a concentration-dependent manner (at doses equal to or above 


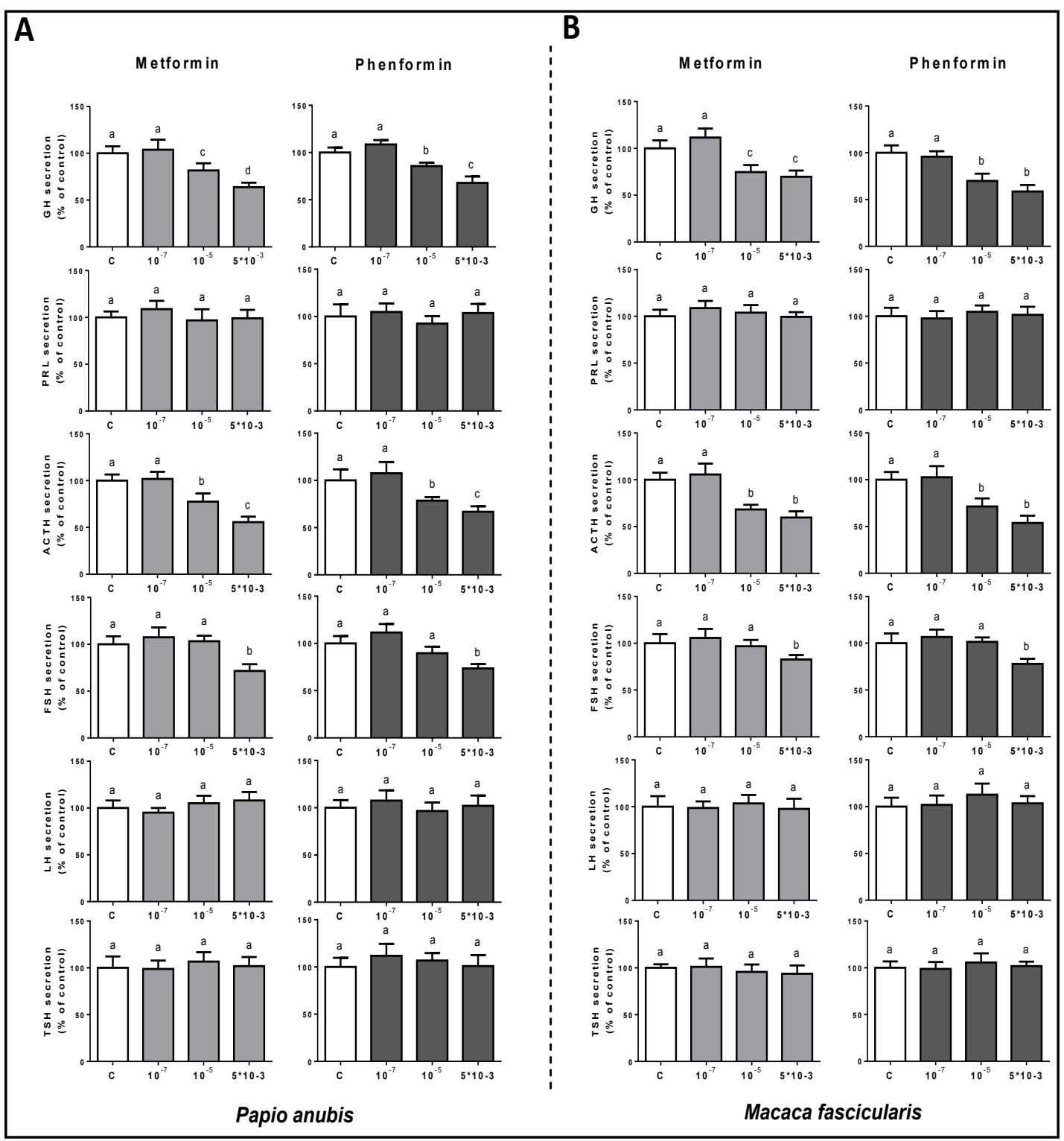

Fig. 1. Dose-response $(4 \mathrm{~h})$ of metformin and phenformin $\left(5 \mathrm{mM}, 10^{-5} \mathrm{M}\right.$ and $\left.10^{-7} \mathrm{M}\right)$ on the secretion of $\mathrm{GH}$, $\mathrm{PRL}, \mathrm{ACTH}, \mathrm{FSH}, \mathrm{LH}$ and TSH in primary pituitary cell cultures from baboons (A: metformin, $\mathrm{n}=4$; phenformin, $n=1)$ and macaques ( $B ; n=3)$. Data are expressed as percent of control (set at 100\%) and represent the mean \pm SEM ( $n=3-4$ wells/experiments). Values that do not share a common letter $(a, b$ and $c)$ are statistically different.

$10^{-5} \mathrm{M}$ for GH/ACTH and $5 \times 10^{-3} \mathrm{M}$ for FSH; Fig. $1 \mathrm{~A}-\mathrm{B}$; $\left.\mathrm{n}=3-4\right)$. Conversely, metformin failed to alter basal PRL, LH or TSH release at all the doses tested (Fig. 1A-B). Treatment with phenformin exerted the same effects than metformin on the secretion of all the pituitary hormones [Fig. 1B; macaque-model $(n=3)$, and a single pilot experiment performed in the baboon-model (Fig. 1A)]. Based on these results, the dose of metformin and phenformin that caused a maximal or significant decrease of GH, ACTH and TSH release, $5 \times 10^{-3} \mathrm{M}$, was chosen to further analyze the action of these agents on primate pituitary function.

Direct effects of metformin and phenformin after a short vs. long incubation period on primate pituitary hormone release

In a separate experiment, treatment with $5 \times 10^{-3} \mathrm{M}$ metformin and phenformin, for different incubation times, i.e. short- (4h) and long-term (24h), confirmed an inhibitory effect 


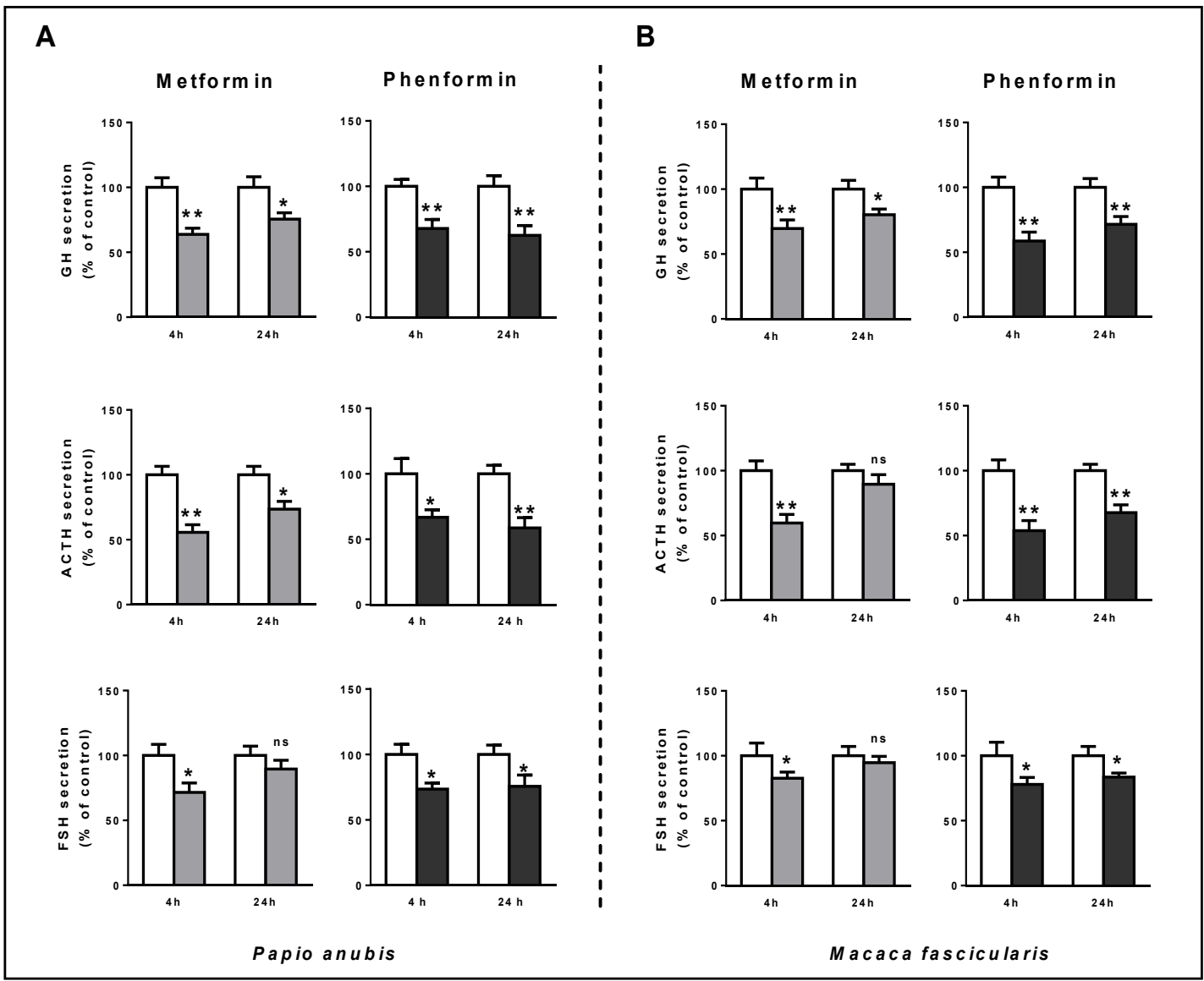

Fig. 2. Time response ( $4 \mathrm{~h}$ and $24 \mathrm{~h}$ ) of metformin and phenformin (5 $\mathrm{mM}$ ) on GH, ACTH and FSH secretion in primary pituitary cell cultures from baboons (A: metformin, $n=3-4$; phenformin, $n=1$ ) and macaques (B; $\mathrm{n}=3$ ). Data are expressed as percent of control (set at 100\%) and represent the mean \pm SEM ( $n=3-4$ wells/ experiments). Asterisks $\left({ }^{*} \mathrm{p}<0.05,{ }^{* *} \mathrm{p}<0.01\right)$ indicate values that significantly differ from their respective control values.

of both biguanides on GH, ACTH and FSH release [Fig. 2A-B (n=3-4); and Fig. 2A (phenformin; $\mathrm{n}=1$ )], but not on PRL, LH or FSH release (data not shown), mostly conserved between $4 \mathrm{~h}$ and $24 \mathrm{~h}$. However, it should be noted that these inhibitory effects were apparently more pronounced after a short-term compared to a long-term incubation-period, being this inhibitory effect not statistically significant for baboon/macaque FSH-release (Fig. 2A-B) and macaque ACTH-release (Fig. 2B) after metformin treatment at 24h.

Direct effects of metformin on primate pituitary hormone expression.

Metformin treatment $\left(5 \times 10^{-3} \mathrm{M}\right)$ clearly reduced the expression levels of $G H$ and proopiomelanocortin (POMC, the ACTH precursor) at $24 \mathrm{~h}$, but not at $4 \mathrm{~h}$ in baboon primary pituitary cells (Fig. 3). In contrast, it did not alter FSHB expression levels (Fig. 3), or those of other pituitary hormones (PRL, LHB or TSHB) at 4- or 24-h (Fig. 3).

Interaction of metformin with key regulators of GH, ACTH and FSH secretion: GHRH, ghrelin and GnRH in primate models

We next tested the direct effects of $4 \mathrm{~h}$ of incubation with metformin alone or in combination with primary stimulatory factors of somatotrope, corticotrope or gonadotrope function, i.e. GHRH, ghrelin and GnRH; [22, 24, 29] (Fig. 4). This first revealed that, as expected, treatment with metformin alone inhibited GH, ACTH and FSH release, whereas GHRH, ghrelin or GnRH alone stimulated GH, ACTH and/or FSH release in primary pituitary cell cultures from baboons and macaques (Fig. 4). Interestingly, co-administration with 


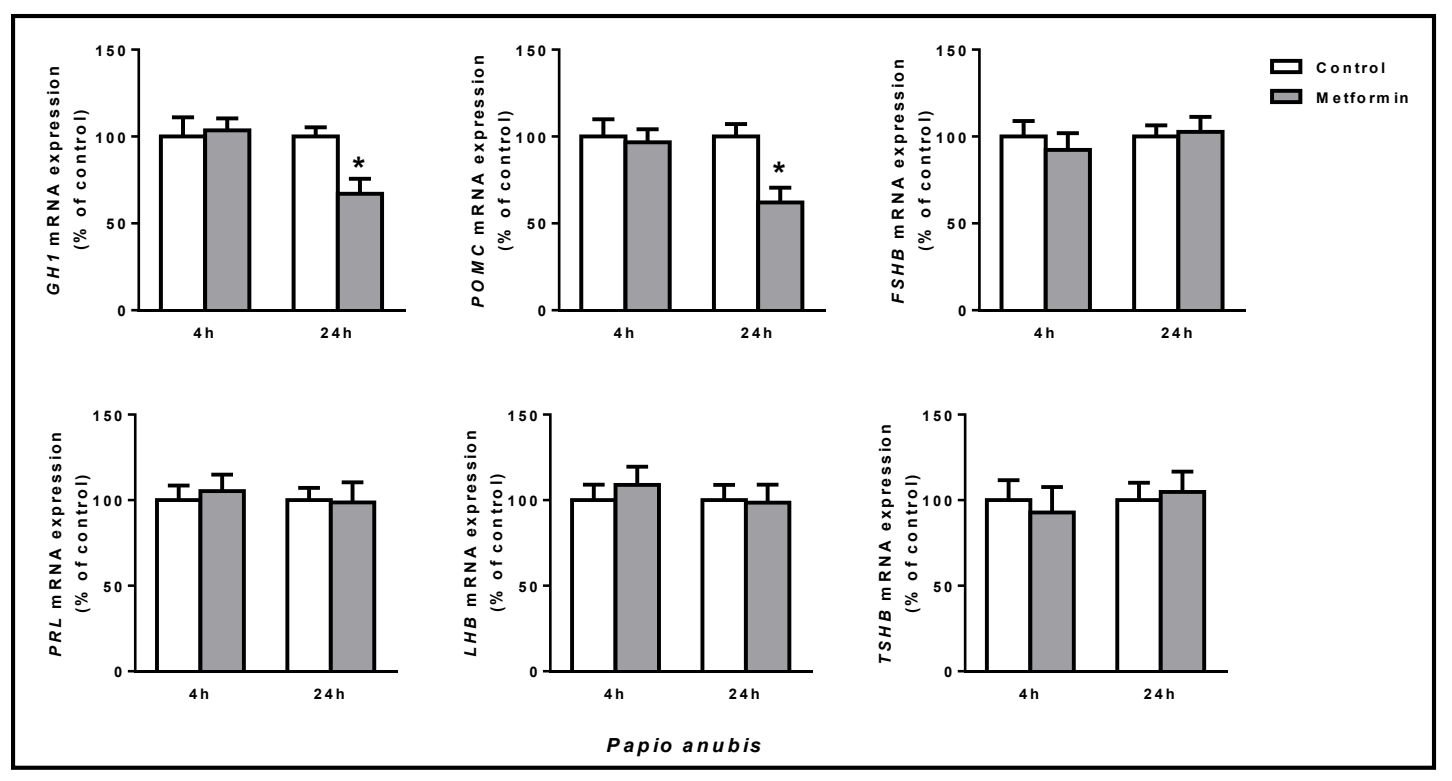

Fig. 3. Direct effect of metformin ( $5 \mathrm{mM}$ ) on mRNA expression of GH1, POMC, FSHB, PRL, LHB and TSHB in baboons. Data are expressed as percent of control (set at 100\%) and represent the mean \pm SEM $(n=3$ individual experiments, $n=3-4$ wells/experiments). Asterisks $\left({ }^{*} \mathrm{p}<0.05\right)$ indicate values that significantly differ from their respective control values.

metformin did not impact the stimulatory actions of GHRH-stimulated GH release, ghrelinstimulated GH or ACTH release, or GnRH-stimulated FSH release (Fig. 4).

\section{Direct effects of metformin on primate pituitary cell viability}

Treatment with metformin and phenformin did not alter cell viability in macaque primary pituitary cell cultures (Fig. 5). Similarly, pilot results from a single experiment performed in baboon primary pituitary cell cultures also indicated that metformin and phenformin treatment did not impact cell viability (data not shown). Moreover, as an indirect measurement of the maintenance of cell number after the treatments with metformin or phenformin in baboon and macaque primary pituitary cell cultures, we analyzed and observed that the recovery of total RNA in the vehicle-treated samples and in the biguanidetreated samples across experiments were markedly constant [RNA concentrations measure using the Ribogreen RNA quantification kit and also a NanoDrop Lite (Thermo Fisher Scientific, Wilmington, DE 19810, USA)], which indirectly confirmed that the treatment with these biguanides did not affect cell viability in normal primary pituitary cell cultures (data not shown).

Intracellular signaling pathways involved in the metformin-induced reductions in GH, ACTH and FSH release in the baboon model

The use of pharmacological inhibitors revealed that metformin inhibits GH, ACTH and FSH release through highly similar, if not identical signaling pathways (Fig. 6A-C, respectively). Specifically, our results indicate that the inhibitory effect of metformin on GH, ACTH and FSH release is likely mediated through mTOR, PI3K and intracellular $\mathrm{Ca}^{2+}$ influx, because incubation with specific blockers of these routes, but not with extracellular $\mathrm{Ca}^{2+}$ influx, $\mathrm{AC}$ or PLC inhibitors, completely blocked the inhibitory effect of metformin on GH, ACTH and FSH secretion (Fig. 6; metformin-columns). Interestingly, blockade of MAPK activity completely abolished the inhibitory effect of metformin on GH, but not ACTH or FSH, secretion (Fig. 6). Importantly, administration of these inhibitors alone did not modify basal GH, ACTH or FSH release (Fig. 6; control-columns). It should be noted that given the limited source of baboon cell preparations, we were able to study only some signaling routes, which were selected based on their importance on the functioning of multiple pituitary cell types [15]. Moreover, we were not able to study AMPK signaling using a similar approach since no specific and reliable pharmacological inhibitor is available to examine its function. 


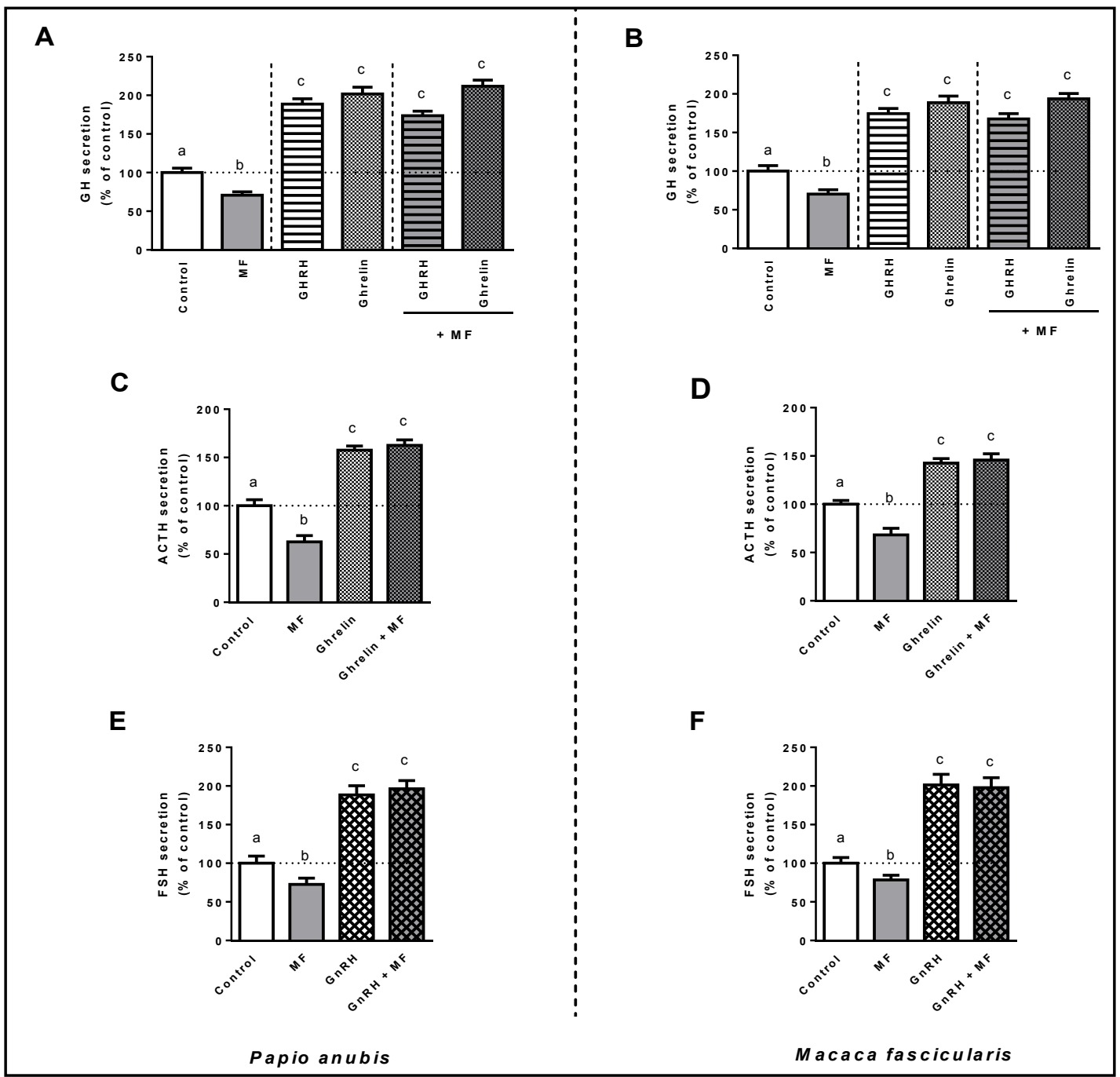

Fig. 4. Effect of $4 \mathrm{~h}$ treatment of GHRH, ghrelin or GnRH (10 $\mathrm{nM}$ ) in absence or presence of metformin (5 $\mathrm{mM}$ ) on $\mathrm{GH}, \mathrm{ACTH}$ and FSH secretion in primary pituitary cell cultures from baboons (A, C, E) and macaques $(B, D, F)$. Data are expressed as percent of control (set at 100\%) and represent the mean \pm SEM (n=3-4 individual experiments, $n=3-4$ wells/experiments). Values that do not share a common letter $(a, b$ and $c)$ are statistically different.

Fig. 5. Effect of metformin ( $5 \mathrm{mM}$ ) on cell viability (24h) of primary pituitary cell cultures from macaques assessed by trypan-blue assay. Results are expressed as percent of control (set at 100\%) and represent the mean \pm SEM $(n=3$ individual experiments, $n=3$ 4 wells/experiments).

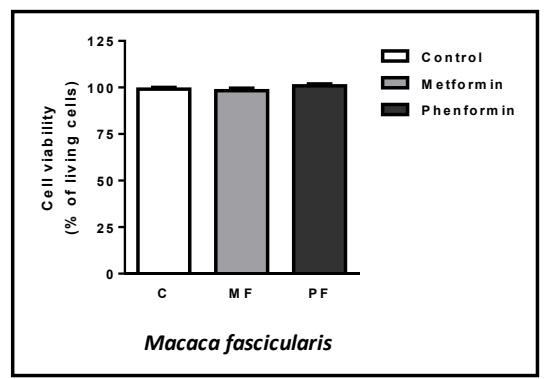




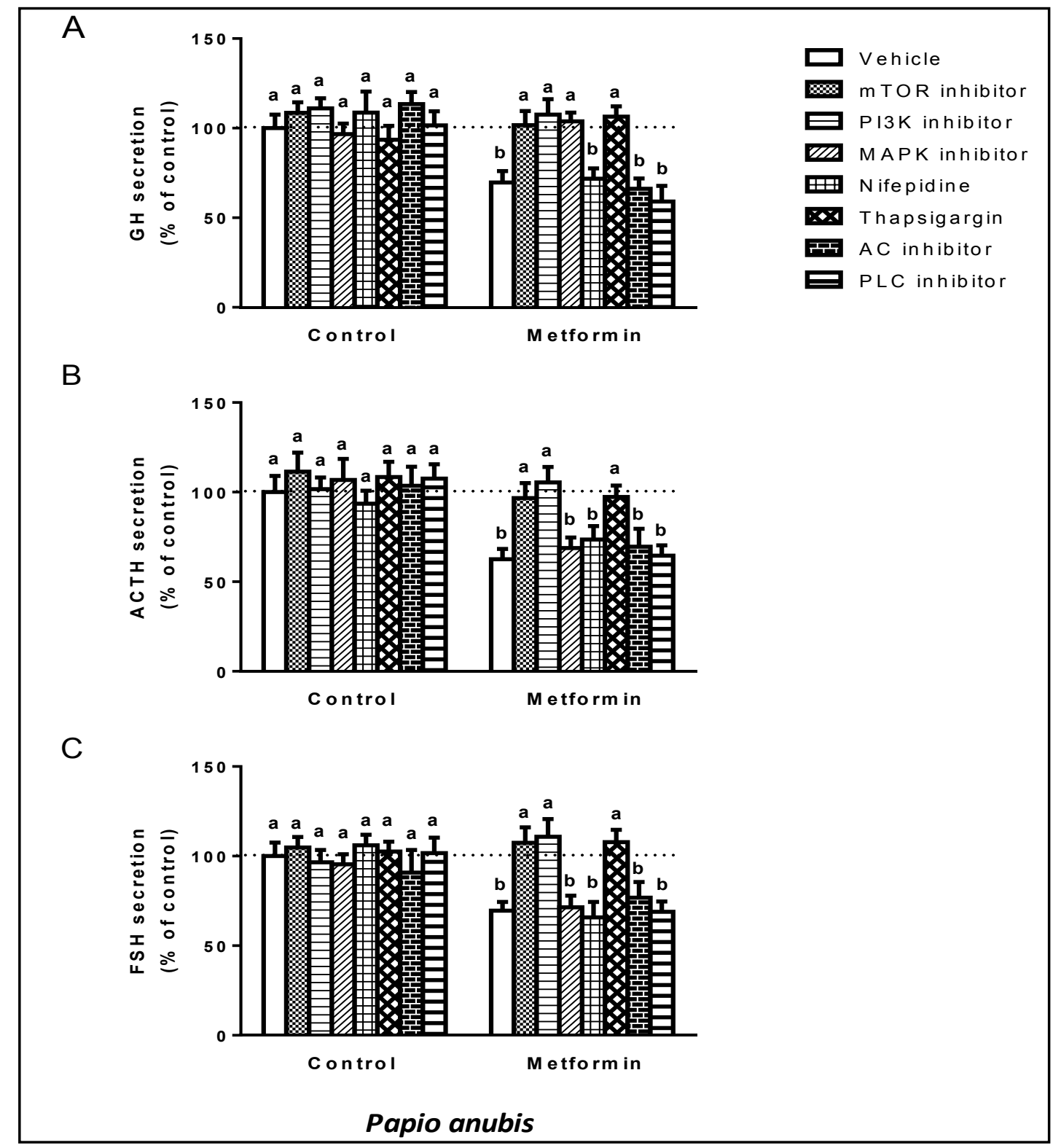

Fig. 6. Intracellular signaling pathways of metformin-regulated baboon GH (A), ACTH (B) and FSH (C). Effect of inhibition of mTOR (rapamycin; $1 \mu \mathrm{M}$ ), PI3K (wortmannin; $1 \mu \mathrm{M}$ ), MAPK (PD-98,059; 10 $\mu \mathrm{M}$ ), extracellular $\mathrm{Ca}^{2+}$ channels (nifepidine; $1 \mu \mathrm{M}$ ), intracellular $\mathrm{Ca}^{2+}$ channels (thapsigargin; $\left.10 \mu \mathrm{M}\right), \mathrm{AC}(\mathrm{MDL}-12,330 \mathrm{~A} ; 10 \mu \mathrm{M})$, and PLC $(\mathrm{U} 73122 ; 50 \mu \mathrm{M})$ on metformin-stimulated hormone release in primary pituitary cell cultures from baboons. Values are expressed as percent of vehicle-treated control without inhibitor (set at $100 \%$ within each experiment) and represent the mean \pm SEM ( $n=3-4$ individual experiments, $n=3-4$ wells/experiments). Values that do not share a common letter $(a, b$ and $c)$ are statistically different.

Direct effects of metformin on the expression of key receptors and a transcriptional factor involved in somatotrope, corticotrope and gonadotrope function.

Next, we studied the direct effect of metformin (24h of incubation) on the mRNA expression of a basic transcription factor for somatotropes, the pituitary transcription factor-1 (POU1F1) (Fig. 7A), and of selected key receptors controlling pituitary physiology (Fig. 7B). Metformin caused clear increases in the expression of key receptors associated to primary regulation of somatotrope, corticoptrope and gonadotrope function, including somatostatin receptor subtypes 2 and 5 (SSTR2 and SSTR5; the two main pituitary receptor 


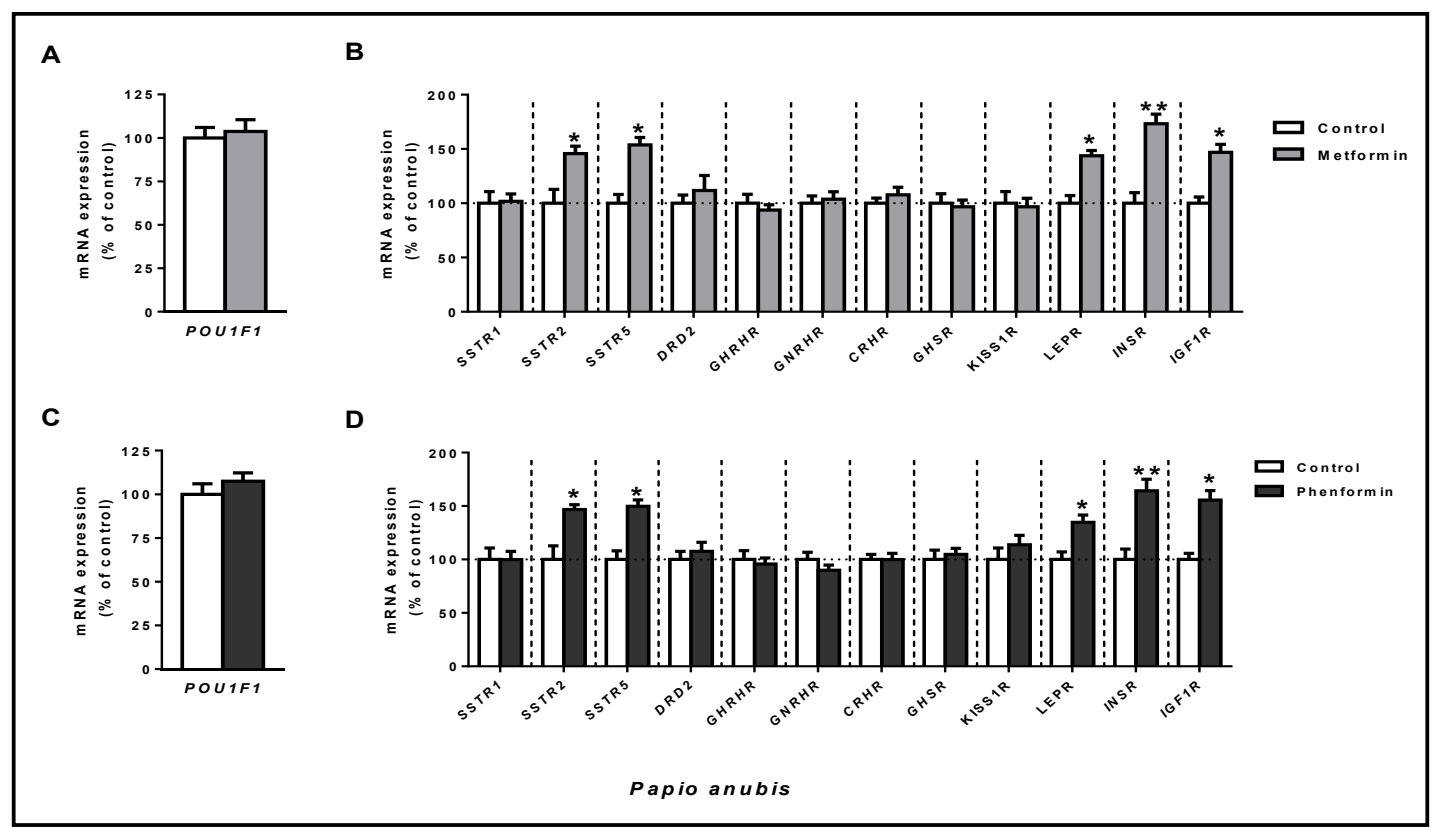

Fig. 7. Direct effect of metformin $(n=3 ; 5 \mathrm{mM})$ and phenformin $(n=1 ; 5 \mathrm{mM})$ on mRNA expression of $(A$, C) the pituitary transcription factor-1 (POU1F1); and (B, D) key receptors involved in the functioning of different pituitary cell-types (SSTR1, SSTR2, SSTR5, DRD2, GHRHR, GNRHR, CRHR, GHSR, KISS1R, LEPR, INSR and IGF1R) in primary pituitary cell cultures from baboons. Data are expressed as percent of control (set at $100 \%)$ and represent the mean \pm SEM ( $n=3-4$ wells/experiments). Asterisks $\left({ }^{*} p<0.05,{ }^{* *} p<0.01\right)$ indicate values that significantly differ from their respective control values.

of the somatostatin system), and the receptors for leptin (LEPR), insulin (INSR) and IGF1 $(I G F 1 R)]$ (Fig. 7B). Conversely, metformin did not alter the expression of POU1F1 (Fig. 7A) or those of other receptors tested (somatostatin receptor subtype 1 (SSTR1), dopamine receptor subtype-2 (DRD2), GHRH-receptor (GHRHR), corticotropin-releasing hormonereceptor $(C R H R)$, ghrelin-receptor (GHSR) or kisspeptin-receptor (KISSR). Moreover, results from a pilot, single experiment revealed that phenformin treatment exerted comparable effects to those observed with metformin on the expression of these receptor and POU1F1 (Fig. 7C-D).

\section{Discussion}

Biguanides are synthetic drugs widely known by their antidiabetic properties, which seem to be primarily mediated by the inhibition of hepatic gluconeogenesis and the increase of glucose uptake in peripheral tissues, such as muscle or fat [2, 3]. However, biguanides are also being thoroughly studied due to their beneficial actions in the modulation of other critical (patho)physiological conditions such as the development of metabolic syndrome, cardiovascular disease or different types of cancer [4-10]. This pleiotropic nature of biguanides has also suggested the existence of additional sites of action (tissue targets) for these compounds. In this context, the "master endocrine gland", i.e. the pituitary gland, could also serve as a suitable target and mediator for the actions of biguanides, owing to its emerging role as a true sensor of alterations in whole body homeostasis and metabolism, by receiving, integrating and processing the information originating from central and peripheral signals, and appropriately conveying it to various key target endocrine and nonendocrine organs (i.e. liver, fat, muscle, etc) [15]. However, the information available about the effects that biguanides exert at the pituitary level is scarce, partially contradictory and somewhat controversial. Specifically, most of the data available mainly derives from early studies conducted in patients with different pathological conditions [i.e. polycystic ovary syndrome (PCOS), hypothyroidism, hyperprolactinaemia, or obesity], which have shown 


\section{Cellular Physiology Cell Physiol Biochem 2018;49:1444-1459 \\ and Biochemistry Published online: 13 September, 2018 \begin{tabular}{l|l} 
DOI: 10.1159/000493448 2018 The Author(s). Published by S. Karger AG, Basel \\
www.karger.com/cpb
\end{tabular} \\ Vázquez-Borrego et al.: Actions of Metformin on Primate Pituitary Function}

that metformin could exert inhibitory actions on LH (but not FSH) TSH, PRL or GH levels, respectively [11,12,17, 18, 31-34]. But, our understanding of the effects of metformin, or other biguanides, in healthy humans remains a subject of intense debate since the available studies are quite limited and indicate that metformin does not seem to significantly impact plasma GH, LH or FSH levels $[11,12]$; however, a caveat should be introduced at this point, because, although these early data undoubtedly have great value for the scientific community, most of this information was generated from studies using metformin for prolonged periods of time. Moreover, to the best of our knowledge, the direct, in vitro, effects of metformin at the pituitary level have been only reported in two studies showing that LH or FSH secretion levels were not altered in response to different doses of metformin after $48 \mathrm{~h}$ of incubation in normal rat primary pituitary cells [26], whereas GH release was significantly reduced by metformin in tumoral GH3 cells and in cultured human GH-producing adenomas [35].

Thus, the question remains: can biguanides directly regulate pituitary function (basal and stimulated hormone release and hormone gene expression) under normal, non-pathological conditions in humans or non-human primates? To address this question, in the current study, we examined whether metformin and phenformin could directly impact hormone release/ expression in primary pituitary cell cultures from normal baboons and macaques. These two primate species are of great interest for translational biomedical research, since they closely model human physiology, and have been frequently used to test a variety of hypotheses that cannot be directly tested in human subjects $[19,20]$. Indeed, this approach provided here the first compelling evidence that metformin and phenformin inhibit somatotrope, corticotrope and gonadotrope function. Specifically, we showed that these biguanides act selectively to suppress basal GH, ACTH and FSH release and that this inhibitory action could be held over time. In fact, the maximal hormone release inhibition was already achieved (for GH, ACTH and FSH) after $4 \mathrm{~h}$ of incubation, and although the inhibitory effect was still observed after long-term (24h) incubation for GH and ACTH, but not FSH, secretion, no further quantitative reduction was appreciable above the initial inhibition observed at $4 \mathrm{~h}$.

In addition, to our knowledge, this is the first report studying, in a cell culture system, the direct interaction between metformin with other primary regulators of somatotrope and corticotrope function. Specifically, we found that metformin treatment did not impact the stimulatory actions of GHRH-stimulated GH release, ghrelin-stimulated GH or ACTH release or GnRH-stimulated FSH release, which might suggest common mechanisms of action between those pituitary hormones-modulators and metformin (as will be further discussed below). It should be mentioned that this latter result is in contrast with the only previous report published to date indicating that GnRH-stimulated FSH and LH was reduced by metformin in rat primary pituitary cell cultures [26]. These discrepancies on the modulation of gonadotropes may be due, in part, to the age, sex and/or reproductive status of the donor, to the time of incubation (short vs. long periods), cell preparation and culture conditions, etc., but also, most likely, to fundamental differences in the physiology of gonadotropes from rat vs. primate species. Nevertheless, although the mechanisms and physiologic relevance behind the actions of metformin and phenformin observed in the present study remain unknown, our results are novel and demonstrate that one of the primary actions of these biguanides are confined to the regulation of basal, non-stimulated, $\mathrm{GH}, \mathrm{ACTH}$ and FSH release. Moreover, these results demonstrate that these effects of both biguanides are conserved across the two primate models analyzed in this study, two species that closely model human genetics and physiology; thence, it is tempting to speculate that these biguanides may exert similar effects in anterior pituitary cells of humans, which set the stage for future investigations. In any case, our current data further extend previous observations, suggesting that the physiological actions of biguanides include a pituitary site of action as well.

Additionally, our data also indicated that the primary actions of metformin in the pituitary of baboons were not confined to the regulation of hormonal secretions, but also included regulation of the synthesis of different hormones. No previous studies have described the direct actions of metformin in the synthesis of all the anterior pituitary hormones in humans or non-human primates. Specifically, our data indicated that the observed inhibitory effects of metformin on baboon GH and ACTH secretion would be directly associated to and reinforced by a decrease in the expression of these hormones (i.e. GH1 and POMC). Moreover, we also found that metformin did not alter PRL, FSHB, LHB and TSHB expression, which closely parallels the lack of effect observed at $24 \mathrm{~h}$ of incubation in the release of these hormones. 


\section{Cellular Physiology Cell Physiol Biochem 2018;49:1444-1459

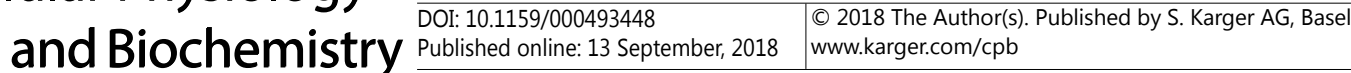 \\ Vázquez-Borrego et al.: Actions of Metformin on Primate Pituitary Function}

Consequently, these data indicate that, whereas the pituitary actions of metformin extend to both hormonal synthesis and release in somatotrope and corticotropes, its effects on gonadotropes only seem to modulate secretory vesicle release, but not FSH expression. Importantly, our results indicate that the inhibitory actions of metformin and phenformin on pituitary cells cannot be attributed to an effect on cell viability or in the expression of the transcription factor Pit-1 since 24h-incubation with these biguanides did not alter cell viability or POU1F1 expression in primate primary pituitary cell cultures.

Our report also provides the first analysis of the different intracellular signaling pathways that underlie the direct effects evoked by metformin on multiple anterior pituitary hormone secretions (i.e. GH, ACTH and FSH release). Specifically, the use of a standard pharmacological (inhibitory) approach revealed that the actions of metformin on GH, ACTH and FSH secretion are mediated by mTOR, PI3K and intracellular $\mathrm{Ca}^{2+}$ mobilization, but not by AC, PLC or extracellular $\mathrm{Ca}^{2+}$ influx. Of note, we also found that the inhibitory actions of metformin on $\mathrm{GH}$, but not ACTH or FSH, secretion also require MAPK. At this point, it is important to mention that AMPK has been classically considered to be a central mediator of metformin effects in different tissues/organs 2; however, this contention remains controversial since numerous reports have also demonstrated AMPK-independent mechanism of actions for metformin $[13,14]$. Indeed, although we were not able to determine the implication of AMPK using this pharmacological approach due to the lack of effective, and accepted, specific inhibitors of AMPK, our data further support the notion that metformin can act through AMPKdependent and -independent pathways. Specifically, we found that three of the signaling pathways that are essential to mediated the actions of metformin at the pituitary (i.e. mTOR, PI3K and intracellular $\mathrm{Ca}^{2+}$ mobilization), have been previously described to be upstream or downstream of AMPK signaling pathway [36-40], which might suggests that metformin might act through these pathways in a AMPK-associated manner at the pituitary level. Additionally, we have also observed that metformin exerts inhibitory effects on GH secretion through pathways not linked with AMPK, such as MAPK signaling, which also demonstrate the existence of AMPK-independent mechanisms in somatotrope cells. Furthermore, the analysis of the different intracellular signaling pathways help to explain the reason why metformin treatment did not impact the stimulatory actions of ghrelin/GHRH /GnRH, as the actions of metformin are associated to the activation of similar and divergent signaling pathways to those evoked by these peptides. Specifically, ghrelin has been associated with the activation of multiple signaling cascades at the pituitary level in non-human primates, including PLC, protein kinase C (PKC), intracellular and extracellular $\mathrm{Ca}^{2+}$ and MAPK [15, 41]; while the signaling pathways associated to GHRH and GnRH include AC/cAMP/ protein kinase A (PKA), NOS/guanylate cyclase (GC) and intra-/extracellular $\mathrm{Ca}^{2+}[15]$. Therefore, this report reveals that metformin, ghrelin, GHRH and GnRH exert their pituitary actions through distinct, but also common (i.e. intracellular $\mathrm{Ca}^{2+}$ and MAPK pathways), signaling pathways, which could explain, in part, why metformin treatment might not influence the stimulatory actions of these peptides at the pituitary level.

Our data indicated that the actions of metformin in the baboon pituitary also include regulation of the sensitivity of somatotropes, corticotropes and gonadotropes to some of their well-known regulatory factors (i.e. insulin, IGF1, leptin and somatostatin), some of which are tightly related with metabolic homeostasis [15, 29, 42-45]. In particular, metformin treatment provoked a significant increase in the expression of key receptors associated to primary inhibition of GH, ACTH and/or FSH secretion (e.g. SSTR2, SSTR5, INSR and IGF1R), which, in conjunction, might also be serving to enhance the inhibitory effects of metformin on the hormone expression and release of somatotropes, corticotropes and gonadotropes observed in these primate models.

\section{Conclusion}

Overall, the results of this report unveil the existence of various regulatory layers for metformin at the secretory, gene expression and signaling levels in the somatotrope, corticotrope and gonadotrope axes; however, there is a temporal dissociation between them. Specifically, signaling and secretory actions are rapid (4h) and can be sustained over time (24h), whereas gene expression effects (GH1, POMC and key regulatory receptors) necessarily require longer periods to be effective [ $24 \mathrm{~h}$, but not at $4 \mathrm{~h}]$, and might represent an additional 


\section{Cellular Physiology Cell Physiol Biochem 2018;49:1444-1459 and Biochemistry Published online:13 September, 2018 \begin{tabular}{l|l} 
DO 2018 The Author(s). Published by S. Karger AG, Basel \\
www.karger.com/cpb
\end{tabular} \\ Vázquez-Borrego et al.: Actions of Metformin on Primate Pituitary Function}

regulatory mechanism to enhance the responsiveness of these pituitary cells to metformin. In this sense, the increase in the expression levels of insulin and IGF-1 receptors observed after $24 \mathrm{~h}$ of incubation with metformin might represent a critical molecular, sensory element at the pituitary level associated to the anti-hyperglycemic and pro-metabolic character of biguanides, wherein metformin would increase the sensitivity to insulin and IGF-1 in different endocrine tissues, including the pituitary, to induce an increment in the uptake of glucose by the cells [46-49].

At the same time, the decrease in the secretion of GH and ACTH could be also one of the primary, beneficial, metabolic actions exerted by metformin to improve whole body homeostasis and metabolism since clinical and experimental studies have established that increased circulating levels of GH and glucocorticoids (secreted in response to pituitary ACTH) can lead to worsening of insulin resistance, glucose intolerance, overt diabetes mellitus [50]. In fact, given that GH is an important regulator of cellular and whole-body metabolism as well as body composition, and that elevation of circulating GH levels causes hyperinsulinemia and insulin resistance [50-55], a reduction in GH levels in response to metformin might be primary mechanism associated with the improved insulin sensitivity observed in response to metformin treatment. Therefore, overall, the results generated in the present study using two non-human primate models reinforce the contention that the pituitary is a primary site for the physiological actions of metformin, and that this gland would represent an additional, key target tissue and a true endocrine sensor contributing, in concert with other primary tissues (i.e. liver), to the well-known beneficial metabolic effects of biguanides in humans.

\section{Acknowledgements}

This work was supported by the following grants: Junta de Andalucía (CTS-1406, BIO0139, PI-0077-2016), Instituto de Salud Carlos III-FIS [co-funded by European Union (ERDF/ ESF, "Investing in your future"; PI16/00264, CP15/00156 and "Miguel Servet" Program], MINECO (BFU2016-80360-R), CIBERobn and Department of Veterans Affairs, Office of Research and Development Merit Award BX001114 (to RDK). Ciber an initiative of Instituto de Salud Carlos III, Ministerio de Sanidad, Servicios Sociales e Igualdad, Spain).

The authors would like to thank the staff of the veterinarian staff of the University of Illinois at Chicago, Biological Resource Center, for its invaluable help, and give special thanks to Lisa Halliday.

\section{Disclosure Statement}

The authors have no competing interests.

\section{References}

1 Foretz M, Guigas B, Bertrand L, Pollak M, Viollet B: Metformin: from mechanisms of action to therapies. Cell metabolism 2014;20:953-966.

2 Pryor R, Cabreiro F: Repurposing metformin: an old drug with new tricks in its binding pockets. Biochem J 2015;471:307-322.

-3 Moreno-Navarrete JM, Ortega FJ, Rodriguez-Hermosa JI, Sabater M, Pardo G, Ricart W, Fernandez-Real JM: OCT1 Expression in adipocytes could contribute to increased metformin action in obese subjects. Diabetes 2011;60:168-176.

4 Tahrani AA, Bailey CJ, Del Prato S, Barnett AH: Management of type 2 diabetes: new and future developments in treatment. Lancet 2011;378:182-197.

-5 Fung CS, Wan EY, Wong CK, Jiao F, Chan AK: Effect of metformin monotherapy on cardiovascular diseases and mortality: a retrospective cohort study on Chinese type 2 diabetes mellitus patients. Cardiovasc Diabetol 2015;14:137.

-6 Novelle MG, Ali A, Dieguez C, Bernier M, de Cabo R: Metformin: A Hopeful Promise in Aging Research. Cold Spring Harb Perspect Med 2016;6:a025932. 


\section{Cellular Physiology Cell Physiol Biochem 2018;49:1444-1459 \begin{tabular}{l|l|l} 
and Bioch 10.1159/000493448 & $\begin{array}{l}\text { @ } 2018 \text { The Author(s). Published by S. Karger AG, Basel } \\
\text { www.karger.com/cpb }\end{array}$ \\
\hline
\end{tabular}}

7 Wang ZD, Wei SQ Wang QY: Targeting oncogenic KRAS in non-small cell lung cancer cells by phenformin inhibits growth and angiogenesis. Am J Cancer Res 2015;5:3339-3349.

-8 Duan W, Chen K, Jiang Z, Chen X, Sun L, Li J, Lei J, Xu Q, Ma J, Li X, Han L, Wang Z, Wu Z, Wang F, Wu E, Ma Q, Ma Z: Desmoplasia suppression by metformin-mediated AMPK activation inhibits pancreatic cancer progression. Cancer Lett 2017;385:225-233.

-9 Rico M, Baglioni M, Bondarenko M, Laluce NC, Rozados V, Andre N, Carre M, Scharovsky OG, Menacho Marquez M: Metformin and propranolol combination prevents cancer progression and metastasis in different breast cancer models. Oncotarget 2017;8:2874-2889.

10 Tong D, Liu Q Liu G, Xu J, Lan W, Jiang Y, Xiao H, Zhang D, Jiang J: Metformin inhibits castration-induced EMT in prostate cancer by repressing COX2/PGE2/STAT3 axis. Cancer Lett 2017;389:23-32.

-11 Billa E, Kapolla N, Nicopoulou SC, Koukkou E, Venaki E, Milingos S, Antsaklis A, Adamopoulos DA: Metformin administration was associated with a modification of $\mathrm{LH}$, prolactin and insulin secretion dynamics in women with polycystic ovarian syndrome. Gynecol Endocrinol 2009;25:427-434.

12 Oride A, Kanasaki H, Purwana IN, Miyazaki K: Effects of metformin administration on plasma gonadotropin levels in women with infertility, with an in vitro study of the direct effects on the pituitary gonadotrophs. Pituitary 2010;13:236-241.

13 Bridges HR, Jones AJ, Pollak MN, Hirst J: Effects of metformin and other biguanides on oxidative phosphorylation in mitochondria. Biochem J 2014;462:475-487.

14 Owen MR, Doran E, Halestrap AP: Evidence that metformin exerts its anti-diabetic effects through inhibition of complex 1 of the mitochondrial respiratory chain. Biochem J 2000;348 Pt 3:607-614.

-15 Vazquez-Borrego MC, Gahete MD, Martinez-Fuentes AJ, Fuentes-Fayos AC, Castano JP, Kineman RD, Luque RM: Multiple signaling pathways convey central and peripheral signals to regulate pituitary function: Lessons from human and non-human primate models. Mol Cell Endocrinol 2018;463:4-22.

16 Musumeci G, Castorina S, Castrogiovanni P, Loreto C, Leonardi R, Aiello FC, Magro G, Imbesi R: A journey through the pituitary gland: Development, structure and function, with emphasis on embryo-foetal and later development. Acta Histochem 2015;117:355-366.

17 Krysiak R, Szkrobka W, Okopien B: Sex-dependent effect of metformin on hypothalamic-pituitary-thyroid axis activity in patients with subclinical hypothyroidism. Pharmacol Rep 2016;68:1115-1119.

18 Krysiak R, Okopien B: The effect of metformin on the hypothalamic-pituitary-thyroid axis in women with polycystic ovary syndrome and subclinical hypothyroidism. J Clin Pharmacol 2015;55:45-49.

19 Ebeling M, Kung E, See A, Broger C, Steiner G, Berrera M, Heckel T, Iniguez L, Albert T, Schmucki R, Biller H, Singer T, Certa U: Genome-based analysis of the nonhuman primate Macaca fascicularis as a model for drug safety assessment. Genome Res 2011;21:1746-1756.

20 Comuzzie AG, Cole SA, Martin L, Carey KD, Mahaney MC, Blangero J, VandeBerg JL: The baboon as a nonhuman primate model for the study of the genetics of obesity. Obes Res 2003;11:75-80.

21 McClure HM: Nonhuman primate models for human disease. Adv Vet Sci Comp Med 1984;28:267-304.

-22 Luque RM, Córdoba-Chacón J, Ibáñez-Costa A, Gesmundo I, Grande C, Gracia-Navarro F, Tena-Sempere M, Ghigo E, Gahete MD, Granata R, Kineman RD, Castaño JP: Obestatin plays an opposite role in the regulation of pituitary somatotrope and corticotrope function in female primates and male/female mice. Endocrinology 2014;155:1407-1417.

23 Kineman RD, Luque RM: Evidence that ghrelin is as potent as growth hormone (GH)-releasing hormone (GHRH) in releasing GH from primary pituitary cell cultures of a nonhuman primate (Papio anubis), acting through intracellular signaling pathways distinct from GHRH. Endocrinology 2007;148:4440-4449.

24 Luque RM, Córdoba-Chacón J, Gahete MD, Navarro VM, Tena-Sempere M, Kineman RD, Castaño JP: Kisspeptin regulates gonadotroph and somatotroph function in nonhuman primate pituitary via common and distinct signaling mechanisms. Endocrinology 2011;152:957-966.

-25 Ibanez-Costa A, Cordoba-Chacon J, Gahete MD, Kineman RD, Castano JP, Luque RM: Melatonin regulates somatotrope and lactotrope function through common and distinct signaling pathways in cultured primary pituitary cells from female primates. Endocrinology 2015;156:1100-1110.

-26 Tosca L, Froment P, Rame C, McNeilly JR, McNeilly AS, Maillard V, Dupont J: Metformin decreases GnRHand activin-induced gonadotropin secretion in rat pituitary cells: potential involvement of adenosine 5' monophosphate-activated protein kinase (PRKA). Biol Reprod 2011;84:351-362.

-27 Vlotides G, Tanyeri A, Spampatti M, Zitzmann K, Chourdakis M, Spttl C, Maurer J, Nolting S, Goke B, Auernhammer CJ: Anticancer effects of metformin on neuroendocrine tumor cells in vitro. Hormones (Athens) 2014;13:498-508.

-28 Córdoba-Chacón J, Gahete MD, Culler MD, Castaño JP, Kineman RD, Luque RM: Somatostatin dramatically stimulates growth hormone release from primate somatotrophs acting at low doses via somatostatin receptor 5 and cyclic AMP. J Neuroendocrinol 2012;24:453-463. 


\section{Cellular Physiology Cell Physiol Biochem 2018;49:1444-1459 \begin{tabular}{l|l|l|}
\hline DOI: 10.1159/000493448 & $\begin{array}{l}\text { C) 2018 The Author(s). Published by S. Karger AG, Basel } \\
\text { www.karger.com/cpb }\end{array}$
\end{tabular}

29 Luque RM, Gahete MD, Hochgeschwender U, Kineman RD: Evidence that endogenous SST inhibits ACTH and ghrelin expression by independent pathways. Am J Physiol Endocrinol Metab 2006;291:395-403.

-30 Sarmento-Cabral A, Peinado JR, Halliday LC, Malagon MM, Castano JP, Kineman RD, Luque RM: Adipokines (Leptin, Adiponectin, Resistin) Differentially Regulate All Hormonal Cell Types in Primary Anterior Pituitary Cell Cultures from Two Primate Species. Sci Rep 2017;7:43537.

-31 Schatz H, Doci S, Hofer R: The effect of dimethylbiguanide on glucose tolerance, serum insulin and growth hormone in obese patients. Diabetologia 1972;8:1-7.

-32 Krysiak R, Okrzesik J, Okopien B: The effect of short-term metformin treatment on plasma prolactin levels in bromocriptine-treated patients with hyperprolactinaemia and impaired glucose tolerance: a pilot study. Endocrine 2015;49:242-249.

-33 Elsersy MAM: Efficacy of Combined Cabergoline and Metformin Compared to Metformin Alone on Cycle Regularity in Patients with Polycystic Ovarian Disease with Hyperprolactinemia: A Randomized Clinical Trial. J Obstet Gynaecol India 2017;67:363-369.

-34 Krysiak R, Szkrobka W, Okopien B: Sex-Dependent Effect of Metformin on Serum Prolactin Levels In Hyperprolactinemic Patients With Type 2 Diabetes: A Pilot Study. Exp Clin Endocrinol Diabetes 2017;10.1055/s-0043-122224.

- 35 An J, Pei X, Zang Z, Zhou Z, Hu J, Zheng X, Zhang Y, He J, Duan L, Shen R, Zhang W, Zhu F, Li S, Yang $\mathrm{H}$ : Metformin inhibits proliferation and growth hormone secretion of GH3 pituitary adenoma cells. Oncotarget 2017;8:37538-37549.

-36 Hawley SA, Pan DA, Mustard KJ, Ross L, Bain J, Edelman AM, Frenguelli BG, Hardie DG: Calmodulindependent protein kinase kinase-beta is an alternative upstream kinase for AMP-activated protein kinase. Cell Metab 2005;2:9-19.

-37 Wang Y, Xu W, Yan Z, Zhao W, Mi J, Li J, Yan H: Metformin induces autophagy and G0/G1 phase cell cycle arrest in myeloma by targeting the AMPK/mTORC1 and mTORC2 pathways. J Exp Clin Cancer Res 2018;37:63.

-38 Han G, Gong H, Wang Y, Guo S, Liu K: AMPK/mTOR-mediated inhibition of survivin partly contributes to metformin-induced apoptosis in human gastric cancer cell. Cancer Biol Ther 2015;16:77-87.

39 Leclerc GM, Leclerc GJ, Fu G, Barredo JC: AMPK-induced activation of Akt by AICAR is mediated by IGF-1R dependent and independent mechanisms in acute lymphoblastic leukemia. J Mol Signal 2010;5:15.

40 Mihaylova MM, Shaw RJ: The AMP-activated protein kinase (AMPK) signaling pathway coordinates cell growth, autophagy, \& metabolism. Nat Cell Biol 2012;13:1016-1023.

41 Yin Y, Li Y, Zhang W: The growth hormone secretagogue receptor: its intracellular signaling and regulation. Int J Mol Sci 2014;15:4837-4855.

42 Gahete MD, Durán-Prado M, Luque RM, Martinez-Fuentes AJ, Vazquez-Martinez R, Malagón MM, Castaño JP: Are somatostatin and cortistatin two siblings in regulating endocrine secretions? In vitro work ahead. Mol Cell Endocrinol 2008;286:128-134.

43 Gahete MD, Cordoba-Chacon J, Lin Q, Bruning JC, Kahn CR, Castano JP, Christian H, Luque RM, Kineman RD: Insulin and IGF-I inhibit GH synthesis and release in vitro and in vivo by separate mechanisms.

Endocrinology 2013;154:2410-2420.

44 Luque RM, Kineman RD: Neuronostatin exerts actions on pituitary that are unique from its sibling peptide somatostatin. J Endocrinol 2018;237:217-227.

-45 Cordoba-Chacon J, Gahete MD, Castano JP, Kineman RD, Luque RM: Homologous and heterologous in vitro regulation of pituitary receptors for somatostatin, growth hormone (GH)-releasing hormone, and ghrelin in a nonhuman primate (Papio anubis). Endocrinology 2012;153:264-272.

-46 Gunton JE, Delhanty PJ, Takahashi S, Baxter RC: Metformin rapidly increases insulin receptor activation in human liver and signals preferentially through insulin-receptor substrate-2. J Clin Endocrinol Metab 2003;88:1323-1332.

47 Santos RF, Nomizo R, Wajhenberg BL, Reaven GM, Azhar S: Changes in insulin receptor tyrosine kinase activity associated with metformin treatment of type 2 diabetes. Diabete Metab 1995;21:274-280.

48 Fantus IG, Brosseau R: Mechanism of action of metformin: insulin receptor and postreceptor effects in vitro and in vivo. J Clin Endocrinol Metab 1986;63:898-905.

49 Lord JM, White SI, Bailey CJ, Atkins TW, Fletcher RF, Taylor KG: Effect of metformin on insulin receptor binding and glycaemic control in type II diabetes. Br Med J (Clin Res Ed) 1983;286:830-831.

50 Yuen KC, Chong LE, Riddle MC: Influence of glucocorticoids and growth hormone on insulin sensitivity in humans. Diabet Med 2013;30:651-663.

51 Moller N, Jorgensen JO: Effects of growth hormone on glucose, lipid, and protein metabolism in human subjects. Endocr Rev 2009;30:152-177.

-52 Luque RM, Gahete MD, Córdoba-Chacón J, Childs GV, Kineman RD: Does the pituitary somatotrope play a primary role in regulating GH output in metabolic extremes? Ann N Y Acad Sci 2011;1220:82-92. 
Cellular Physiology Cell Physiol Biochem 2018;49:1444-1459 \begin{tabular}{l|l|l} 
and Biochemistry $10.1159 / 000493448$ & $\begin{array}{l}\text { C) } 2018 \text { The Author(s). Published by S. Karger AG, Basel } \\
\text { www.karger.com/cpb }\end{array}$ \\
\hline
\end{tabular}

Vázquez-Borrego et al.: Actions of Metformin on Primate Pituitary Function

53 Kim SH, Park MJ: Effects of growth hormone on glucose metabolism and insulin resistance in human. Ann Pediatr Endocrinol Metab 2017;22:145-152.

54 Yuen KC, Dunger DB: Therapeutic aspects of growth hormone and insulin-like growth factor-I treatment on visceral fat and insulin sensitivity in adults. Diabetes Obes Metab 2007;9:11-22.

55 Groop L, Segerlantz M, Bramnert M: Insulin sensitivity in adults with growth hormone deficiency and effect of growth hormone treatment. Horm Res 2005;64 Suppl 3:45-50. 